\title{
Prohibition of Violations of Heavy Human Rights
}

\author{
Ni Ketut Sari Adnyani ${ }^{1 *}$ \\ ${ }^{1}$ Department of Law and Civics, Ganesha University of Education, Singaraja, Indonesia
}

\section{A R T I C L E I N F O}

Article history:

Received 18 December

2020

Received in revised form

20 December 2020

Accepted 18 February 2021

Available online 25

February 2021

Keywords:

Human Rights, Genocide,

Responsibility of The State

\begin{abstract}
A B S T R A C T
This study aims to analyze the clause on protecting human rights Article 2 of the UDHR and the state responsibility for the types of genocide crimes of Article 6 of the Rome Statute as a response to the fanaticism of religion, culture, freedom, anarchy, radicalism, and underestimating pluralism, which tends to discriminate, witness and allowing people to kill, kill, and rape large numbers of nations. Type of normative legal research. The research approach used is a statutory approach and a case study approach. The results show that human rights violations by borrowing the concept of performative self-contradiction from the theory of criminology, legal protection, and state responsibility provide protection for citizens who assert their rights are severely limited by Article 2 of the UDHR's human rights protection clause and responsibility Article 25 states against the protection of human rights. Further understanding and unifying the various legal cases that Article 6 has produced so far: both target political human rights violations, attack liberal democracy in general; and the abuse of exclusive human rights, attacking the rights of others. Category of genocide or not, we need to pay attention to 2 (two) things, namely Actus Reus (action) and Mens Rea (evil intention) in action.
\end{abstract}

Copyright (C) Universitas Pendidikan Ganesha. All rights reserved.

\section{Introduction}

Indonesia recognizes and upholds human rights and basic human freedoms as rights inherent by nature and inseparable from humans, which must be protected, respected and upheld for the sake of enhancing human dignity, welfare, happiness, intelligence and justice. Furthermore, every human being has the right to life, the right not to be tortured, the right not to be enslaved, the right to be recognized as a person and equality in law, and the right not to be prosecuted on the basis of retroactive law. human beings who cannot be reduced under any circumstances and by anyone (UU No. 39 Tahun 1999). Meanwhile, the universally applicable conception of human rights is contained in the Universal Declaration of Human Rights, which was proclaimed on December 10, 1948 by the UN general assembly, which contains the points of freedom, equality and property ownership., rights in marriage, work rights, and freedom of religion (Davenport \& Amstrong, 2004; Sriram, 2004). The existence of regulations on human rights that have been universally and nationally recognized must be respected and upheld by all parties, whether the state, international organizations, individuals, both individually and collectively (Orentlicher, 1991). It is only with maximum protection and respect that human rights can truly be upheld in the real life of the community, both nationally and internationally.

Human rights violations are violations or negligence of human obligations committed by one person towards another. Based on existing facts, since the proclamation of the DUHAM, there have been many gross human rights violations that have occurred in this part of the world. The presence of the International Criminal Court based on the 1998 Rome Statute is expected to be able to accept, examine and try existing cases with the aim of providing penalties for the perpetrators of gross human rights violations that are categorized as genocide crimes. For this crime, every human being has the responsibility (obligatio erga omnes) to carry out a just punishment. In response to this situation, everyone considers the perpetrator of this crime to be the enemy of all humans. creatures (hostishumanis generis) and every country has an obligation to prosecute the perpetrators (obligatio erga omnes) (UN Commission on Human Rights, 2005). The final society represented by the United Nations (UN), countries, and experts has a serious commitment to punishing international criminals, because the crimes are 
categorized as the most serious. Evidence of the seriousness of the international community is the birth of international agreements regulating these crimes, namely the 1998 Rome Statute concerning the International Criminal Court and the United Nations Convention against Transnational Crime which was held in 2000 (Shaw, 2008).The Rome Statute of 1998 stipulates 4 (four) types of the most serious crimes under the jurisdiction of the Court, namely the crime of genocide, the focus of the analysis refers to the term genocide in the Law of the Republic of Indonesia Number 26 of 2000 concerning Human Rights Courts, which in Article 7 regulates gross human rights violations include: a. genocide crimes, and b. crimes against humanity. UU no. 26/2000 draws material from the 1998 Rome Statute, but is not a form of ratification of the 1998 Rome Statute.

The first crime to be called the most serious crime against the international community is the crime of genocide as stipulated in Article 6. Article 6 of the Rome Statute of 1998 states that "genocide means ethnic, racial or religious groups", as any act committed with the intention of destroying all or some nations, tribes, races and religions. This paper gives a message that the perpetrators of the most serious crimes must be tried, tried and sentenced to show how the perpetrators cannot be free from punishment, despite their position as state officials. These include the Nurenberg Court, the Tokyo Court (International Military Tribunal for the Far East / IMTFE), ICTY, ICTR and ICC. The Nurenberg Court and the Tokyo Court in 1948 were the beginning of the prosecution process for the perpetrators of gross human rights violations. In 1993 the Ad Hoc International Criminal Court was established to try serious or serious offenses that occurred in the former Yugoslavia and in 1994 the ad hoc International Criminal Court was established to try crimes against Genocide, Violations of the Geneva Conventions and Crimes Against Crime. Humanity that happened in Rwanda. After 2002, the International Criminal Court also began hearing a number of cases relating to crimes against humanity.

Types of crimes referred to as gross human rights violations in the Indonesian context. So that the term human rights court which gives rise to the term gross human rights violations comes from the most serious crime (the most critical crime). According to the Rome Statute of 1998, it can be interpreted that lawmakers are aware that this type of genocide is a very serious crime. This is also strengthened by the explanation in this law that, 'gross human rights violations are "extraordinary crimes" and have a wide impact both at the national and international levels and are not criminal acts regulated in the Indonesian Criminal Procedure Code. Based on the aforementioned background, this article aims to analyze the Article 2 of the UDHR's human rights protection clause and Article 25 of the state's responsibility for the types of genocide crimes Article 6 of the Rome Statute.

This study aims to analyze the clause on protecting human rights Article 2 of the UDHR and the state responsibility for the types of genocide crimes of Article 6 of the Rome Statute as a response to the fanaticism of religion, culture, freedom, anarchy, radicalism, and underestimating pluralism, which tends to discriminate, witness and allowing people to kill, kill, and rape large numbers of nations.

\section{Methods}

This research is a normative legal research. This research approach uses a statutory approach, and the case approach examines a legal approach with a policy orientation. From the analysis of the Article 2 Human Rights Protection clause of the UDHR and Article 25 of the state's responsibility for the types of genocide crimes Article 6 of the Rome Statute, it can be analyzed that the normative problem is the absence of norms or empty norms and the formulation of ideal norms of sustainable universal human rights enforcement by considering aspects philosophy of justice and and human rights that there is no place of refuge for the perpetrators of this genocide crime.

\section{Results and Discussions}

Gross Human Rights Violations Threaten World Peace and Security Based On Analyzing Article 2 of The UDHR's Human Rights Protection Clause and Article 25 of The State's Responsibility for Genocide, Article 6 of The Rome Statute

According to the DUHAM, there are (5) five types of human rights possessed by each individual, namely; 1) personal rights (the right to guarantee personal needs); 2) legal rights (legal protection guarantee rights); 3) civil and political rights; 4) substance rights (the right to guarantee the existence of resources to support life); and 5) economic, social and cultural rights (Ubaedillah \& Rozak, 2015).

The Covenant on Civil and Political Rights (ICCPR) as affirmed in Articles 3 s.d. Article 21 of the Universal Declaration of Human Rights can be classified into 5 human rights groups, namely: a) the right to life, freedom and individual safety; b) personal rights which include freedom of expression, freedom of religion, freedom of movement and so on; c) the right to receive equal treatment before the law and 
government (rights of egal equality); d) the right to freedom of peaceful assembly (rights of peaceful assembly); e) political rights, namely the right to participate in government, the right to vote (to vote and be elected in general elections) (Sabon, 2014).

Three elements of state responsibility for gross human rights violations based on close reading of Article 25: factual activities covered by rights that can be violated, this right can be accepted for a purpose, and this goal is the destruction of human rights. Convention rights. Serious human rights violations that follow the definitions contained in the Rome Statute can be understood as a category of crime is seen as a gross human rights violation if the crime involves a certain group of people, who on the orders of their superiors, their leaders, commanders or certain people, systematically try to eliminate a group of people. others mainly for political reasons. In this situation the state's responsibility arises because of a violation of the state's obligations under international law. Responsibility is divided into: state responsibility, individual responsibility, and command responsibility (Anggreni et al., 2020).

Serious human rights violations usually refer to violations of non-derogable rights or violations of ius cogens committed by the state or state officials against its citizens. What is meant by non-derogable rights (rights that cannot be reduced or postponed for fulfillment and protection under any circumstances) here are several civil and political rights guaranteed in the Covenant on Civil and Political Rights (ICCPR), namely the right to life (article 6 ), the right not to be tortured (article 7), the right not to be enslaved (article 8), the right not to be imprisoned solely on the basis of the inability to fulfill an obligation in the agreement (article 11), the right not to be punished for acts that are not constitutes a criminal offense at the time the act is committed (article 15), the right to recognition as a person before the law (article 16), and the right to freedom of thought, conscience and religion (article 18) (McCormick \& Mitchell, 1997)

Several conventions derived from the UDHR and the Covenant on Civil and Political Rights specifically also protect non-derogable rights, such as the Convention Against Torture (CAT), for example, which explicitly states the status of the right not to get torture as non-derogable rights as stated in article 2 paragraph (2): "There are no exceptional circumstances, whether a state of war or threat of war, domestic political instability or a state of emergency, which can be used as justification for torture". Ius cogens is a general norm in international law that is agreed upon, accepted, and recognized by countries in the international community as a whole as a norm that cannot be violated or reduced and can only be changed if more countries in the world agree, accept, and recognizes another norm which is consistent with it (Vienna Convention on the Law and Treaties, 1958).

The subsequent development of the discourse on international human rights law, violations of non-derogable rights as stated in the ICCPR and elaborated in several more specific human rights conventions are also considered violations of ius cogens, for example torture (Harris \& Sivakumaran, 2004). Serious violations of human rights occur when a country allows or even commits through its apparatus serious crimes or extra ordinary crimes which have been agreed as international crimes; and or the state fails or does not want to hold accountable state officials who commit the crime. Even though it is an absolute necessity for the world community to prosecute the perpetrators of international crimes (obligatio erga omnes) because these perpetrators are the common enemy of all mankind (hostis humanis generis).

The statutes and practices of the Tokyo, Nuremberg, ICTY, ICTR, and Rome Statute courts are the most important sources of international law that make definitive contributions to what is now known as international crimes. The Statute of the Nuremberg and Tokyo Courts in 1945 was the first to describe crimes that are currently considered international crimes, namely crimes against peace, war crimes, and crimes against humanity (Harris \& Sivakumaran, 2004).

In addition, it was at the Nuremberg and Tokyo trials that the concept of individual criminal responsibility was first recognized. Starting from the precedent contributed by the two international courts, on November 21, 1947, after the second world war, the United Nations formed the International Law Commission through UN General Assembly Resolution No. 174 (II). This commission is tasked with compiling a standard of international law that is used by each member state of the UN. At the 48th session of the meeting, which lasted from May to July 1996, the International Law Commission succeeded in agreeing to adopt a series of norms or principles of international law summarized in 20 articles of the "Draft Code of Crimes Against Peace and Security of Mankind".

The Preambule Statute of the ICTR affirms another international tribunal, namely the International Criminal Tribunal for Rwanda (ICTR) which was established through UN Security Council Resolution no. S / RES / 955 of 1994, in its statute8 states that the scope of the court's jurisdiction is to try those responsible for international crimes that fall under the ICTR's jurisdiction, namely: genocide (article 2); crimes against humanity (article 3; and violation of article 3 of the 1949 Geneva Conventions and Additional Protocol II of 1977 (article 4). 
The Draft Statute for an International Criminal Court, which became the forerunner of the Rome Statute, which is also the work of the International Law Commission, states that what is meant by international crimes and will be under the jurisdiction of international criminal courts are crimes of genocide, crimes of aggression, serious violations of the laws and customs that apply to armed conflicts, crimes against humanity, and crimes committed in connection with a treaty constitute very serious crimes of an international nature which constitute very serious crimes of an international nature.

Another important contribution of the Rome Statute is the explicit inclusion of crimes in the form of sexual assault as crimes against humanity and war crimes. Some of the acts that can fall into these two categories are: rape, sexual slavery, forced prostitution, forced pregnancy, forced sterilization, or other forms of sexual violence that have equal gravity (article 7 paragraph 1b ) (article 8 paragraph 2.b.xxii) (article 8 paragraph 2.e.vi). The Statute does not differ in substance from that contained in existing international law in this matter. The detailed and explicit inclusion of this sexual crime act in the jurisdiction of the Court is a critical reinforcement that rape and other forms of sexual assault in certain situations are the most serious crimes of international concern (Drew et al., 2011).

In view of the possibility of a complaint with the Court, Article 25 should or should not be considered, and does not imply that the state should, under the Convention, take action. The concept of human rights is no longer seen in a relatively-specific manner, but is a broadened horizon that can cover both fundamental and universal human aspects. Legality is what makes humans need to be protected legally, formally, both through law and law, nationally and internationally (Chan, 2010). Serious violations of human rights threaten world peace and security based on the analysis of Article 2 of the UDHR human rights protection clause and Article 25 concerning state responsibility for genocide, Article 6 of the Rome Statute that the legal system for resolving gross human rights violations through the International Criminal Court based on the 1998 Rome Statute.

\section{The Factors That Cause Human Rights Violations in Terms of Analyzing Article 2 Of The UDHR's Human Rights Protection Clause and Article 25 Of The State's Responsibility for The Types of Genocide Crimes Article 6 of The Rome Statute}

A conflict can take different forms and occur under different circumstances. In situations of conflicts in Africa, conflicts can be divided into several types, namely personal and individual conflicts, between two individuals and "Kumunal" conflicts, namely conflicts between clans (and), ethnic groups, ethnic groups. tribes, religious groups or between regions. when a group takes up arms against the state, it is called a rebellion. Meanwhile, conflicts between two individuals are often triggered by ethnic or clan issues (Bethuel Kiplagat, 2005). These conflicts are usually prolonged and cause many victims among the community.

According to Kiplagat, among 53 countries on the African continent, there are 35 member countries of the Organization of African Unity-OAU (Organization of African Unity) that are suffering from conflict. The majority of conflicts are categories of rebellions against the state, organized by groups based on regionalism, ideology, race or ethnicity that take up arms against the government / State. (Rebellions against the state, organized by groups based on region, ideology, race or ethnicity who take up arms against the state). These conflicts, not only on the African continent, but also in all parts of the world.

Fearon \& Laitin (2003), quoting Collier, states that the causes of ethnic war, which are "a combination of economic, greed and political ineptitude, rather than religious, ethnic o other forms of grievance, that accounts for the rise of civil violence". Thus, ethnic conflicts, apart from being caused by ethnic (and religious) conflicts, are also instigated by civil society. Meanwhile, Duncan and Holfman state that the causes of ethnic conflict are the proliferation of weapons, the economy, and the development of democratic politics through social disintegration (Uyangoda, 2007). The cause of the conflict, according to Duncan and Holfman, was more focused on political factors and government policies.

The issue of ethnic discrimination, exclusivity from development processes, violations of minority rights, which are associated with the exclusivity of the Tamil community from the division of State power to the central government are follow-up issues. Second, what is usually understood as the root cause of conflict is only part of the struggle for conflict. Identification of the dynamics and consequences of conflict is fundamentally equally important. For example, the proliferation of conflict through a protracted cycle of violence is a major dynamic of conflict. In the same way, war has become a humanitarian problem which includes mass displacement, destruction of life and property as well as social and economic infrastructure in northern and eastern Sri Lanka. The protracted war and violence have also frozen over ethnic identity, strengthening hostility among ethnic communities, has formed ethnic pockets in an area (Uyangoda, 2007). In several countries in Africa, where the community composition is multi-ethnic, one of the causes of prolonged ethnic conflict is divisive politics carried out by the colonialists, similar to what happened in Sri Lanka. These conflicts tend to be uncontrollable and lead to bloodshed. 
Similar to ethnic / ethnic backgrounds, religion is also a trigger for conflict. Little identified 3 specific areas where religion and other grievances were linked to the intensity of conflict, namely (1) helping to legitimize insurgents; (2) assisting and recruiting insurgents; and (3) introducing critical objects and areas of dispute, such as the placement of holy places, and accommodation for religious beliefs and practices (David Little. 2009: 17).

Since the recognition of religion, wars have been fought. Until now, much of the violence that occurred in conflicts was related to religious elements, which were also related to ethno-national, interstate, economic, regional, cultural and other issues. Conflicts based on religion tend to continue, and become brutal wars of all kinds. When conflicts are written in religious terms, the conflict is transformed into conflicts of values.

In contrast to other problems such as conflicts over natural resources, which can be resolved by means of a practical or distributive manner, conflicts of value have a tendency to be collectively determined. These conflicts demand strong justifications for what is good and wrong, and the parties believe that there will be no common ground for resolving their differences. Since the North-South conflict in Sudan emerged in religious ways, they have developed a deep commonality of value conflicts that seem insurmountable, except through violence or separation (unresolved except by force or separation) (Assefa, 1990). The opinions mentioned above state that there are 3 main causes of conflict with a religious background, namely, politics and state policies, fanaticism and the inaccessibility of a religion, which in turn creates conflict.

Apartheid case arose for the first time in South Africa. The case of apartheid stems from the discovery of diamond fields by the British and Dutch in the 17th century. After independence, there were two groups which later divided power over South Africa, which was later won by the Nationalist Party. To perpetuate its power, the Party then pursued a strategy of creating apartheid as a way to tighten their control over the economic and social system. Initially, the aim of apartheid was to maintain white domination while at the same time expanding racial segregation. Then in the early 1960's, the leadership of the State created and implemented a plan called "Grand apartheid" which emphasized territorial separation and repressive policies.

By enacting the Apartheid Act, racial discrimination was institutionalized. The racial laws touched every aspect of social life, including the prohibition of marriage between whites and non-whites, and stipulated that only whites held state positions. Also, the government enacted the Population Registration Act which required that all South Africans be racially classified into three categories, namely white, black (African) and colored (mixed), who usually came from India and Asia in general (Bethuel Kiplagat, 2005).

Then, how do human rights violations occur? Continuing the above case, if there is someone who killed someone else, or someone who castrated other people's opinions by force, or locked up a school-age child for not attending school, then all of these cases are criminal cases and must be resolved in the District Court, not Human Rights Court. The problem is different, if the state is aware of the aforementioned number of events and the state has not taken any action to protect the rights of the victims in these events, then the state has committed human rights violations against citizens or to humans within its sovereign territory (human rights violations by commission). This approach will clarify the old case law and help incorporate some systems into widespread cases. This paper recommends a special "test" to find examples of genocide crimes as gross human rights violations. This test will then be practiced by reviewing relevant legal cases. It turns out that the Commission and the Court implicitly used the same approach so far and checked whether a particular action was contrary to the values of the Convention. I claim, however, that Article 6 does not only target contradictions, but self-contradictions. To analyze one of the legal cases, for example whether the actions taken against Rohingans in Myanmar are genocide or not, we need to observe 2 (two) things, namely Actus Reus (actions) and Mens Rea (evil intentions) in these actions. First, genocide is as stated in Article 6 of the Rome Statute that has been elaborated. At present there are indeed many versions related to what actually happened in Myanmar in various media. However, most of the media reported that there had been a large number of killings and rapes against the majority of the Rohingans who were Muslim. If this is indeed the case, then at least the elements in points (a), (b), and (c) Article 6 of the Rome Statute have been fulfilled. Second, what really needs to be considered is Mens Rea, it is important to prove that the actions taken against the Rohingans are structured actions that are intended to eliminate the Rohingans as a whole.

The following is a more in-depth study of article 6, referring to the basis for consideration the declaration made by the United Nations General Assembly in resolution 96 (I) of December 11, 1946 that genocide is a crime under international law, contrary to the soul and goals of the United Nations, and condemned by the civilized world, recognizing all historical period, genocide has caused huge losses to humanity, and believes that in order to free humankind from this disgusting disaster, international cooperation is needed. For now, focus purely on his words and leave the legal case. Then, the idea of 
multikausa self-contradiction will be introduced to help identify examples of genocidal crime. Examining the genocide problem comprehensively by examining the compatibility between law in book and law in action.

Classification of Article 2 of the 1948 Genocide Convention and Article 6 of the Rome Statute, genocide crimes fall under the jurisdiction of the International Criminal Court. To assess whether it should be applied not only to the main perpetrators of genocide who can be convicted by the International Criminal Court, other perpetrators related to genocide can also be punished. The perpetrators of genocide are not only the direct perpetrators of genocide, but also those who carry out the omission, including the act of attempting to commit genocide, can be punished as if committing genocide. This has nothing to do with a correct understanding of the concept of serious human rights crimes and generally does not change the outcome of a case. The court, it is hoped, follows both approaches. I want to avoid debating around the correct classification of Article 6, because this has received a lot of scientific attention. For the purposes of this article, I claim that the multikausa self-contradiction test can be applied in any way. It must therefore be seen as a minimum threshold, not as a single criterion, which must be demonstrated by a case that Article 25 can be adopted in examining the element of genocide outlined in Article 6.

Because the notion of gross human rights violations and cases related to genocide is somewhat unclear, it seems advisable to start with the basics. The first reading reveals that the basic provisions contain three elements. This will allow us to group legal cases into three categories. When trying to understand the phenomenon of genocide, Mark Levene argues that: "any broad historical examination of the phenomenon of genocide cannot fruitfully proceed without engagement with issues of collective human psychopathology" (Jones, 2006).

This expression presents one of the approaches that have been taken to explain the causes of genocide, namely a psychological approach carried out by delving into the psychological space of the culprit. Perspectives on sociology and anthropology. In terms of the potential for genocide, ethnic conflicts co-exist with other conflicts that have the potential to lead to genocide, namely racial conflicts, religious conflicts, and national conflicts.

\section{The Form of Settlement of Gross Human Rights Violations According to The Analysis of Article 2 of the UDHR's Human Rights Protection Clause and Article 25 of the State's Responsibility for The Types of Genocide Crimes Article 6 Of The Rome Statute}

This declaration is known as "The Universal Declaration of Human Rights", dated December 10, 1948 is a legal provision relating to race, ethnicity or religion, regulated in Article 2 of this Declaration, which states that everyone has the right to all rights and freedoms contained in this declaration without any exception, such as differences in race, color, sex, language, religion, politics or other views, national or social origin, property rights, birth or other status (Begem et al., 2019).

The existence of an international criminal court with the ratification of the Rome Statute by several countries is an advancement in the enforcement of international criminal law. The international criminal court has the authority to investigate several types of crimes that are classified as extraordinary (extra ordinary crimes) such as genocide, war crimes, crimes against humanity and aggression.

The presence of the international criminal court also changes the pattern of international criminal law enforcement, from previously indirect enforcement to a model of direct enforcement, (Neumayer, 2005). In addition, international criminal court in relation to jurisdiction is complementary. This means that the ICC will be complementary or alternative if a country's judiciary shows an inability and unwillingness to resolve gross human rights violations. If it is related to the Indonesian context, the existence of an international criminal court based on the Rome statute will fully support the human rights court process as regulated in Law Number 26 of 2000 concerning Human Rights Courts which are part of the national criminal law enforcement system.

In article 33 of the Charter of the United Nations, it is explained that in order to resolve cases, diplomacy should be used first before going to the realm of law. It reads as follows: Paragraph 1, Parties involved in a dispute which, if it continues continuously, may endanger the maintenance of national peace and security, must first seek a settlement by way of negotiation, investigation, mediation, conciliation, arbitration, settlement. according to law through regional bodies or arrangements, or by other peaceful means of their own choosing. 17 Paragraph 2, If deemed necessary, the Security Council asks the parties concerned to settle their disputes in such ways.

There are diplomatic mechanisms that can be used to resolve genocide cases by using Mediation. Mediation is a method of settlement through negotiations involving a third party as a mediator. The third party here is referred to as a mediator. The mediator here is not only the state but can be individuals, international organizations and so on. For example, regarding one of the genocide cases that occurred in the Rohingya ethnicity, the UN could act as a mediator to mediate between the disputing parties (ethnic 
Rohingya with the Myanmar government and citizens of Myanmar citizens). As well as the UN can help provide suggestions for the parties to solve problems that occur without one party being aggrieved (Arianta, et al., 2020).

If in using the mediation method, the state has used it in ending the problem that occurred, but it is still unable to resolve the problem, with this the case that occurs can be taken over by the UN Security Council to be resolved using the method through the International Criminal Court.

Taking into account the four jurisdictions in the ICC, namely, Sefriani (2007: 14): (1) Rationae materiae: crimes that have been committed such as genocide, crimes against humanity, war crimes, and crimes of aggression, as described in articles 5-8 of the 1998 Rome Statute. In connection with the cases that happened, the Rohingy ethnic group was a crime against humanity. (2) Rationae personae: based on article 25 of the Rome Statute of 1998, the ICC only tries individuals regardless of whether they are a state official and so on. In connection with the case that occurred in Myanmar, here it is the person responsible for the actions taken. (3) Ratione loci: The ICC may adjudicate cases that occur in participating countries where the crime occurred. This is regulated in article 12 of the 1998 Rome Statute. (4) Ratione temporis: based on article 11 of the 1998 Rome Statute, that the ICC is only may try crimes committed after 1 July 2002.

Regarding the case that occurred in Myanmar, that crimes that occurred after that date. Even though Myanmar is not a participating country that ratified the international criminal court, that does not mean that crimes committed against his ethnic roots cannot be prosecuted through the International Criminal Court. Because all citizens are under the jurisdiction of the International Criminal Court in one of the following conditions: first, the country where the location of the incident has ratified the international criminal tribunal agreement; second, the country has recognized the jurisdiction of the international criminal tribunal on an ad hoc basis; third, the UN Security Council submits the case to the international criminal court (Sefriani, 2007). So, the case can be tried using the ICC.

There are three important documents that must be considered in resolving cases of gross human rights violations, namely regarding the international criminal court (International Criminal Court), proof (Rules of Evidence), and elements of crime (Elements of Crime) so that there are no mistakes in resolving cases of violations HAM's weight. Based on the Rome Statute in the trial of cases of human rights violations the principle of non-retroactivity applies. But many people argue that if retroactivity is not applied, many perpetrators of serious crimes in the past have not been touched by the law.

To settle a case of gross human rights violations, the prosecutor must prove that the crime was carried out with mens rea, that is, it was done intentionally and the consequences were known. The defendant will be responsible for crimes committed jointly or with the same purpose, for acts of assisting or ordering crimes, committing crimes, and attempting to commit crimes by taking the necessary steps to resolve them. This Statute applies to heads of state, elected representatives, and those who have taken action in an official capacity, as persons holding positions in an official organization or government. This principle also undermines or erases impunity that is often attached to those who have power (Begem, et al, 2019).

Article 64 (2) of the Statute mandates the court to proceed fairly and with full respect for the rights of the accused. One of them according to article 67 (c) must be tried 'without delay' if the delay is illegal and detrimental, and is caused by the inability of the prosecutor or other actors outside the power of the defendant, then the only way that the court can do it fulfilling this principle is to cancel the charges and release the defendant.

Article 66 of the Statute perpetuates the principle of presumption of innocence and places the burden on the prosecuting attorney to prove his guilt for convincing reasons. Article 67 (i) suggests that evidence and evidence cannot be sacrificed to the defendant. The issue of the burden and standard of evidence will be a very important factor in court proceedings. In practice, when the claim has proven beyond doubt the gross violation of human rights, the hard task that makes the evidence of innocence, such as coercion or unconscious or guilty circumstances, will move to the defendant.

\section{Conclusion}

Based on a number of descriptions above, it can be concluded that the causes of genocide can include ethnic backgrounds in fighting for minority rights; religious background manifested by fanaticism and racial background manifested through cultural discrimination. The main causes of genocide include ethnic conflicts, racial conflicts and conflicts with religious backgrounds, namely, politics and state policies, fanaticism and the inaccessibility of a religion, which in turn creates conflict. The prohibition of genocide crimes is regulated, either through international law (treaties and decisions of the international court of justice), as well as by the provisions of national law (basic laws, laws and presidential decrees. 
Based on article 33 of the un charter, the disputing parties (ethnic rohingya and the government of myanmar and citizens of myanmar) can solve the problem of genocide in cases of genocide of ethnic rohingya that occurred by using mediation first. If this method does not work, the un security council can submit cases that occur to international courts such as the international criminal court which is regulated in the rome statute of 1998.

\section{References}

Anggreni, I. A. K. N., Mangku, D. G. S., \& Yuliartini, N. P. R. (2020). Analisis Yuridis Pertanggungjawaban Pemimpin Negara Terkait Dengan Kejahatan Perang Dan Upaya Mengadili Oleh Mahkamah Pidana Internasional (Studi Kasus Omar Al-Bashir Presiden Sudan). Jurnal Komunitas Yustisia, 2(3), 227236. http://dx.doi.org/10.23887/jatayu.v2i3.28787

Arianta, K., Mangku, D. G. S., \& Yuliartini, N. P. R. (2020). Perlindungan Hukum Bagi Kaum Etnis Rohingya Dalam Perspektif Hak Asasi Manusia Internasional. Jurnal Komunitas Yustisia, 3(2), 166-176. http://dx.doi.org/10.23887/jatayu.v3i2.28849

Assefa, H. (1990). Religion in the Sudan: Exacerbating Conflict or Facilitating Reconciliation? Bulletin of Peace Proposals, 21(3), 255-262. https://doi.org/10.1177\%2F096701069002100302

Begem, S. S., Qamar, N., \& Baharuddin, H. (2019). Sistem Hukum Penyelesaian Pelanggaran Hak Asasi Manusia (HAM) Berat Melalui Mahkamah Pidana Internasional. SIGn Jurnal Hukum, 1(1), 1-17. https://doi.org/10.37276/sjh.v1i1.28

Bethuel Kiplagat. 2005. "Role of Religion in Conflict Resolution. Relationship between State and Religious of Organization", Institut Universitaire de Hautes Etudes Internationales.

Chan, T. (2010). Moore's paradox is not just another pragmatic paradox. Synthese, 173(3), 211-229. https://doi.org/10.1007/s11229-008-9403-x

Davenport, C., \& Armstrong, D. A. (2004). Democracy and the violation of human rights: A statistical analysis from 1976 to 1996. American Journal of Political Science, 48(3), 538-554. https://doi.org/10.1111/j.0092-5853.2004.00086.x

Drew, N., Funk, M., Tang, S., Lamichhane, J., Chávez, E., Katontoka, S., ... \& Saraceno, B. (2011). Human rights violations of people with mental and psychosocial disabilities: an unresolved global crisis. The Lancet, 378(9803), 1664-1675. https://doi.org/10.1016/S0140-6736(11)61458-X

Fearon, J. D., \& Laitin, D. D. (2003). Ethnicity, insurgency, and civil war. American political science review, 97(1), 75-90. https://www.jstor.org/stable/3118222

Harris, D. J., \& Sivakumaran, S. (2004). Cases and materials on international law (Vol. 134). Sweet \& Maxwell.

Jones, A. (2010). Genocide: A comprehensive introduction. Routledge.

Kitab Undang-Undang Hukum Pidana (KUHAP).

Kovenan Internasional Hak Sipil dan Politik (ICCPR).

McCormick, J. M., \& Mitchell, N. J. (1997). Human rights violations, umbrella concepts, and empirical analysis. World Politics, 510-525. https://www.jstor.org/stable/25054017

Neumayer, E. (2005). Do international human rights treaties improve respect for human rights? Journal of conflict resolution, 49(6), 925-953. https://doi.org/10.1177\%2F0022002705281667

Orentlicher, D. F. (1991). Settling accounts: The duty to prosecute human rights violations of a prior regime. Yale Law Journal, 2537-2615. https://doi.org/10.2307/796903

Preambule Statuta ICTR.

Protokol I Konvensi Geneva tertanggal 8 Juni 1977.

Protokol tambahan Konvensi Geneva 12 Agustus 1949.

Sabon, M. B., \& SH, M. (2020). Hak Asasi Manusia: Bahan Pendidikan untuk Perguruan Tinggi. Penerbit Universitas Katolik Indonesia Atma Jaya. 
Sefriani, S. (2007). Yurisdiksi ICC terhadap Negara non Anggota Statuta Roma 1998. Jurnal Hukum IUS QUIA IUSTUM, 14(2).

Shaw, M. N. (2008). International law. Cambridge University Press.

Sriram, C. L. (2004). Confronting past human rights violations. Routledge.

Statuta Roma. Statute for an International Criminal Court (Statuta Mahkamah Pidana Internasional).

Ubaedillah \& Abdul Rozak. (2008). Pendidikan Kewarganegaraan, Demokrasi, Hak Asasi Manusia dan Masyarakat Madani, Indonesian Center for Civic Education (ICCE). Kencana Prenada Media.

UN Commission on Human Rights, Report of the Independent Expert to Update the Set of Principles to Combat Impunity (E / CN.4 / 2005/102 / Add.1), February 8, 2005.

UN General Assembly, Rome Statute 1998, Article 5 (1).

Undang-Undang Nomor 39 Tahun 1999 tentang Hak Asasi Manusia.

Undang-Undang Republik Indonesia Nomor 26 Tahun 2000 tentang Pengadilan Hak Asasi Manusia.

UUD Negara Republik Indonesia Tahun 1945

Uyangoda, J. (2007). Ethnic conflict in Sri Lanka: changing dynamics. Departemen of Political Science and Public Policy: University of Colombo.

Vienna Convention on the Law and Treaties, 1958. 